\title{
Characterization of Iron-mediated Peroxidative Injury in Isolated Hepatic Lysosomes
}

\author{
I. Tong Mak and William B. Weglicki \\ Cardiovascular Research Program, Oklahoma Medical Research Foundation, Oklahoma City, Oklahoma 73104
}

\begin{abstract}
Peroxidative degradation of the lysosomal membrane and the resultant release of hydrolytic enzymes may be responsible for hepatocellular injury in iron toxicity. In this study, highly purified hepatic lysosomes were exposed to iron salts in vitro; the nature of this iron-mediated process of injury and the susceptibility of the lysosomal integrity were studied. Native hepatic lysosomes from rats were isolated by free flow electrophoresis. Incubation of the lysosomes at $37^{\circ} \mathrm{C}$ with $\mathrm{Fe}^{3+}-\mathrm{ADP}$ in the presence of ascorbate resulted in rapid generation of malondialdehyde, which approached a plateau at $20 \mathrm{~min}$. Subsequently, the loss of lysosomal latency, determined as an increased percentage free activity of $\boldsymbol{N}$-acetyl- $\boldsymbol{\beta}$-glucosaminidase, also occurred and reached a maximum loss at $30 \mathrm{~min}$. The half-maximal level of ascorbate, required to promote the $\mathrm{Fe}^{3+}$ ADP mediated lysosomal peroxidation, was $\sim 10 \mu \mathrm{M}$; high concentrations of ascorbate were inhibitory and half-maximal inhibition was achieved at a concentration of $2 \mathrm{mM}$. The ironmediated lysosomal peroxidation was not inhibited by most active oxygen scavengers and appeared to depend solely on the generation of $\mathrm{Fe}^{2+}$ species. When a fresh solution of $\mathrm{Fe}^{2+}$ was incubated with the lysosomes, both the extent of lipid peroxidation and the degree of latency loss increased as a function of increasing $\mathrm{Fe}^{2+}$ concentration. High concentrations of $\mathrm{Fe}^{2+}$ stimulated lysosomal lipid peroxidation instantaneously and reached the highest level within $10 \mathrm{~min}$; whereas the subsequent maximum loss of latency was achieved within 20 min. Both the MDA formation and the loss of latency in either the $\mathrm{Fe}^{3+}$-ADP + ascorbate or the $\mathrm{Fe}^{2+}$ system were effectively prevented by the presence of vitamin $A$ or vita$\min \mathbf{E}$.
\end{abstract}

\section{Introduction}

Excess iron, whether chronic or acute, is toxic to biological systems, but the mechanism of toxicity is unclear (1). The clinical manifestations of toxic accumulations of iron in various tissues include hepatic fibrosis, disorders of cardiac function, diabetes, and other endocrine abnormalities $(1,2)$. Inorganic iron in certain chelated forms has been demonstrated to be capable of promoting free radical-mediated peroxidation of unsaturated lipids in many lipid peroxidation models (3-5). It has thus been postulated that the iron deposits may catalyze the formation of free radicals, which in turn may peroxidize

\footnotetext{
Address correspondence to Dr. Mak.

Received for publication 25 June 1984 and in revised form 24 August 1984.
}

J. Clin. Invest.

(c) The American Society for Clinical Investigation, Inc. 0021-9738/85/01/0058/06 \$1.00

Volume 75, January 1985, 58-63 the membrane lipids of cellular and subcellular organelles resulting in their structural and functional alterations (6). Animals receiving intraperitoneal injections of either iron salts or ferric nitrilolacetate resulted in increased alkane production in the expired gases, indicating that excessive iron caused increased lipid peroxidation in the whole animal $(7,8)$. A study by Bacon et al. (9) reported that increased conjugated diene formations in the lipids of the microsomal and mitochondrial/lysosomal fractions of the tissue were associated with iron accumulation in liver after in vivo administration of iron. These observations provide evidence of iron-induced lipid peroxidation in the subcellular membranes in the affected tissue.

Of apparent importance to cellular pathogenesis is the susceptibility of the lysosome to iron-mediated reactions resulting in extensive intracellular digestion by the released hydrolases. Compared to the studies with microsomes and mitochondria, very limited work has been reported on the direct effect of iron on the integrity of the lysosome, perhaps partly due to the difficulties involved in isolating the purified organelles on a preparative scale. By using the technique of free flow electrophoresis (10), we have been able to prepare relatively purified "native" hepatic lysosomes that are highly latent. The present report represents an effort to characterize the time course of injury of the purified hepatic lysosomes during exposure to "free iron" (both ferric and ferrous iron salts) in vitro; the role of ascorbate and the mechanism of initiation of this iron-mediated peroxidative process were also studied.

\section{Methods}

Chemicals. ADP, $\mathrm{FeCl}_{3} \cdot 6 \mathrm{H}_{2} \mathrm{O}, \mathrm{FeSO}_{4} \cdot 7 \mathrm{H}_{2} \mathrm{O}$, ascorbic acid, superoxide dismutase (type I, bovine blood; $2,800 \mathrm{U} / \mathrm{mg}$ ), catalase (thymol free, bovine liver; $17,600 \mathrm{U} / \mathrm{mg}$ ), mannitol, DL- $\alpha$-tocopherol and transretinol (type $\mathrm{X}$ ) were purchased from Sigma Chemical Co., St. Louis, MO. 2,5-Dimethylfuran and 1,4-diazabicyclo[2,2,2]-octane (DABCO) ${ }^{1}$ were obtained from Aldrich Chemical Co., Milwaukee, WI.

Preparation and incubations of lysosomes. Highly purified hepatic lysosomes (30- to 60-fold enriched) from male Sprague-Dawley rats $(150-250 \mathrm{~g})$ were prepared by the technique of free-flow electrophoresis as described $(10,11)$. Briefly, the light mitochondrial fraction containing the bulk of the lysosomes was obtained by centrifuging the post-heavy mitochondrial supernatant (supernatant at $5,000 \mathrm{~g}$ for $5 \mathrm{~min}$ ) at 20,000 $g$ for $10 \mathrm{~min}$. The pellet was "washed" four times at $20,000 \mathrm{~g} \times 10$ min as described. The final pellet was resuspended in the electrophoresis buffer consisting of $0.3 \mathrm{M}$ sucrose, $0.01 \mathrm{M}$ triethanolamine, $0.001 \mathrm{M}$ EDTA, and $0.01 \mathrm{M}$ acetate adjusted to $\mathrm{pH} 7.4$ by $\mathrm{NaOH}$. The running conditions of the free flow electrophoresis unit (Desaga 48, Heidelberg, Federal Republic of Germany) were: $100 \mathrm{~mA}, 800 \pm 50 \mathrm{~V}$ at $3^{\circ} \mathrm{C}$;

1. Abbreviations used in this paper: DABCO, 1,4-diazabicyclo[2,2,2]octane; $\mathrm{OH}$, hydroxyl radical; MDA, malondialdehyde; NAGA, $N$ acetyl- $\beta$-glucosaminidase; SOD, superoxide dismutase; $\mathrm{O}_{2}^{-}$, superoxide radical. 
sample flow, $4 \mathrm{ml} / \mathrm{h}$; and buffer flow, $3 \mathrm{ml} / \mathrm{h}$ per fraction. The lysosome enriched fractions were pooled and pelleted at $20,000 \mathrm{~g}$ for $20 \mathrm{~min}$. The lysosomes used for the experiments routinely exhibited 18-25\% free activity of $N$-acetyl- $\beta$-glucosaminidase (NAGA) indicating that the organelles remained relatively intact throughout the isolation procedure.

The purified lysosomes were resuspended in the reaction buffer consisting of $120 \mathrm{mM} \mathrm{KCl}, 50 \mathrm{mM}$ sucrose and $10 \mathrm{mM}$ potassium phosphate, $\mathrm{pH}$ 7.2. The final incubation mixture contained $0.20-0.25$ $\mathrm{mg} / \mathrm{ml}$ of lysosomal protein in the presence or absence of various scavengers as described in the text. The reaction of $\mathrm{Fe}^{3+}$-ADP + ascorbate was initiated by the final additions of $\mathrm{Fe}^{3+}$-ADP $(0.1 \mathrm{mM}$ $\mathrm{FeCl}_{3}$ chelated by $1 \mathrm{mM} \mathrm{ADP}$ ) and ascorbate (usually $0.1 \mathrm{mM}$ ). The reaction of ferrous iron was initiated by the final addition of $\mathrm{FeSO}_{4}$ solution which was prepared immediately before incubation.

The rates of lipid peroxidation (malondialdehyde formation) were determined by the thiobarbituric acid method as described previously (10). The lysosomal marker enzyme NAGA was assayed according to Ruth and Weglicki (12). Percentage-free activity was calculated as (activity in $0.25 \mathrm{M}$ sucrose)/(activity in $0.1 \%$ Triton X-100). Unless specified, changes in percent-free activity of NAGA represented actual alterations in latency of the lysosomes rather than artifactual activation or inactivation of the enzyme by the different incubation conditions. Protein determinations were performed according to Lowry et al. (13).

\section{Results}

Peroxidation of lysosomes by ferric iron and the role of ascorbate. $\mathrm{Fe}^{3+}$ in the presence of ascorbic acid is a powerful catalyst for peroxide formation in microsomal suspension from rat liver $(3,14)$. Table I shows the ability of $\mathrm{Fe}^{3+}-\mathrm{ADP}$ in the presence of ascorbate to induce lysosomal lipid peroxidation. Incubation of the lysosomes in buffer alone or with $\mathrm{Fe}^{3+}-\mathrm{ADP}$ or ascorbate alone for $30 \mathrm{~min}$ produced very low levels of lipid peroxide. However, $\mathrm{Fe}^{3+}$-ADP and ascorbate together greatly stimulated the malondialdehyde (MDA) formation in the lysosomes. Corresponding to the stimulation of lipid peroxide formation, additions of $\mathrm{Fe}^{3+}$-ADP and ascorbate together resulted in almost total loss of lysosomal latency as indicated by the dramatic elevation of percent-free activity of NAGA (90.3 $\pm 6.7 \%$-free); whereas incubations of the lysosomes, in buffer control or with ascorbate or $\mathrm{Fe}^{3+}$-ADP alone, only

Table I. Effect of Ascorbic Acid on Fe $\mathrm{Fe}^{3+}$-ADP-induced Peroxidative Damage on Purified Hepatic Lysosomes

\begin{tabular}{lll}
\hline Conditions & MDA formed & $\begin{array}{l}\text { Percent free } \\
\text { activity of NAGA }\end{array}$ \\
\hline & $n m o l / m g$ protein & \\
Control & $1.07 \pm 0.39$ & $32.3 \pm 3.0$ \\
$\mathrm{Fe}^{3+}$-ADP & $2.23 \pm 0.50^{*}$ & $33.0 \pm 2.5$ \\
$\mathrm{Ascorbic}^{*}$ acid & $1.13 \pm 0.25$ & $32.6 \pm 3.0$ \\
$\mathrm{Fe}^{3+}$-ADP plus ascorbate & $67.0 \pm 5.8 \ddagger$ & $90.3 \pm 6.7 \ddagger$ \\
\hline
\end{tabular}

Lysosomes (0.20-0.25 $\mathrm{mg}$ protein $/ \mathrm{ml}$ ) were incubated in a medium of $120 \mathrm{mM} \mathrm{KCl}, 50 \mathrm{mM}$ sucrose, $10 \mathrm{mM}$ potassium phosphate, $\mathrm{pH}$ 7.2 at $37^{\circ} \mathrm{C}$ for $30 \mathrm{~min}$. The indicated additions were $\mathrm{Fe}^{3+}$-ADP $(0.1$ $\mathrm{mM} \mathrm{FeCl}, 1 \mathrm{mM} \mathrm{ADP}$ ) and ascorbate $(0.1 \mathrm{mM})$. MDA formation and percent-free activity of NAGA in the samples were measured as described in Methods. Values are means \pm SD of four separate preparations.

$* P<0.05$

$\ddagger P<0.01$ vs. values for control. resulted in modest levels of percent-free activities of NAGA ( $\sim 33 \%$-free) over the same period of incubation (Table I).

Fig. 1 displays the temporal correlation between the rate of ascorbate dependent $\mathrm{Fe}^{3+}$-ADP induced lipid peroxidation and the rate of loss of latency in the lysosomes. With the additions of $\mathrm{Fe}^{3+}$-ADP and ascorbate, MDA formation proceeded readily and reached a plateau at $\sim 20 \mathrm{~min}$. The loss of the latent activity of the lysosomal NAGA, however, lagged behind and reached a maximum level after $30 \mathrm{~min}$ of incubation at $37^{\circ} \mathrm{C}$. Although ascorbic acid is a vitamin in vivo, the mechanism by which ascorbate acts in biological systems remains obscure. It has been shown to be either a promoter of oxidation or an antioxidant in microsomal lipid peroxidation (14-16). Fig. 2 indicates that with $\mathrm{Fe}^{3+}$-ADP (0.1-1 mM) maintained constant, ascorbate $(<100 \mu \mathrm{M})$ exhibited a logdose-dependent enhancement of the lysosomal lipid peroxidation with a half-maximal level of $\sim 10 \mu \mathrm{M}$. However, ascorbate levels higher than $500 \mu \mathrm{M}$ were inhibitory and the half-maximal inhibition was achieved by $2 \mathrm{mM}$. Complete inhibition was observed at an ascorbate concentration $>4$ $\mathrm{mM}$. At different concentrations, ascorbate also increased or reduced the percentage-free activity of NAGA to an extent that was closely associated with the degree of MDA formation in the lysosomes. Linear regression analysis indicates a positive correlation $(r=0.98$, slope $=0.630)$ between MDA generation after $30 \mathrm{~min}$ incubation and percent-free activity of NAGA. Incubations of the lysosomes with ascorbate alone did not cause significant changes in percent-free activity of NAGA from the buffer controls (data not shown). The combined data thus suggest that lysosomal membrane destabilization is linearly

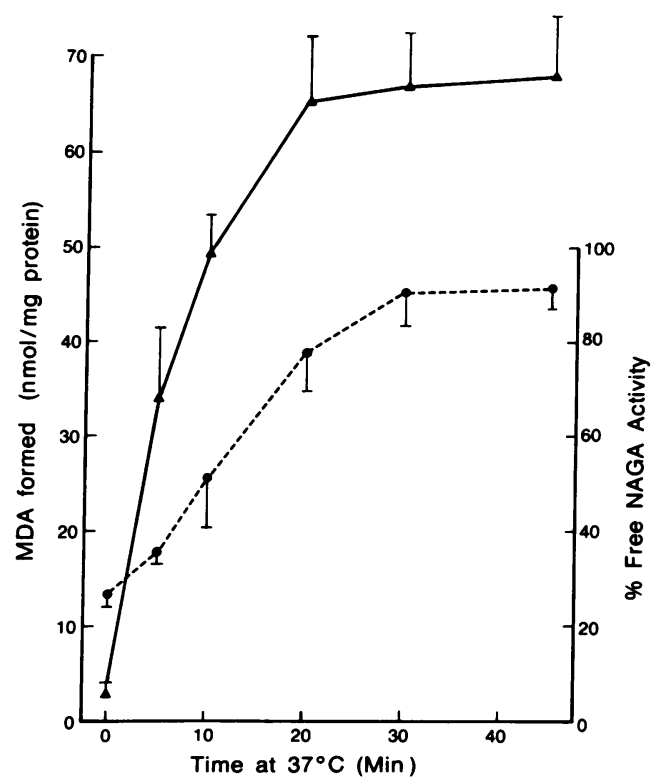

Figure 1. Time course of lipid peroxidation and loss of latency in lysosomes incubated with $\mathrm{Fe}^{3+}$-ADP + ascorbate at $37^{\circ} \mathrm{C}$. Lysosomes $(0.20-0.25 \mathrm{mg}$ protein $/ \mathrm{ml})$ were incubated with the additions of ascorbate $(0.10 \mathrm{mM})$ and $\mathrm{Fe}^{3+}$-ADP $(0.1 \mathrm{mM} \mathrm{FeCl}, 1 \mathrm{mM}$ ADP $)$ in a buffer of $120 \mathrm{mM} \mathrm{KCl}, 50 \mathrm{mM}$ sucrose and $10 \mathrm{mM}$ potassium phosphate, pH 7.2. At indicated time of incubation, samples were assayed for MDA formation ( $\Delta-\Delta)$ and percent-free activity of NAGA $(\bullet . . .-\bullet)$ as described in Methods. Values are mean \pm SD of four separate preparations. 


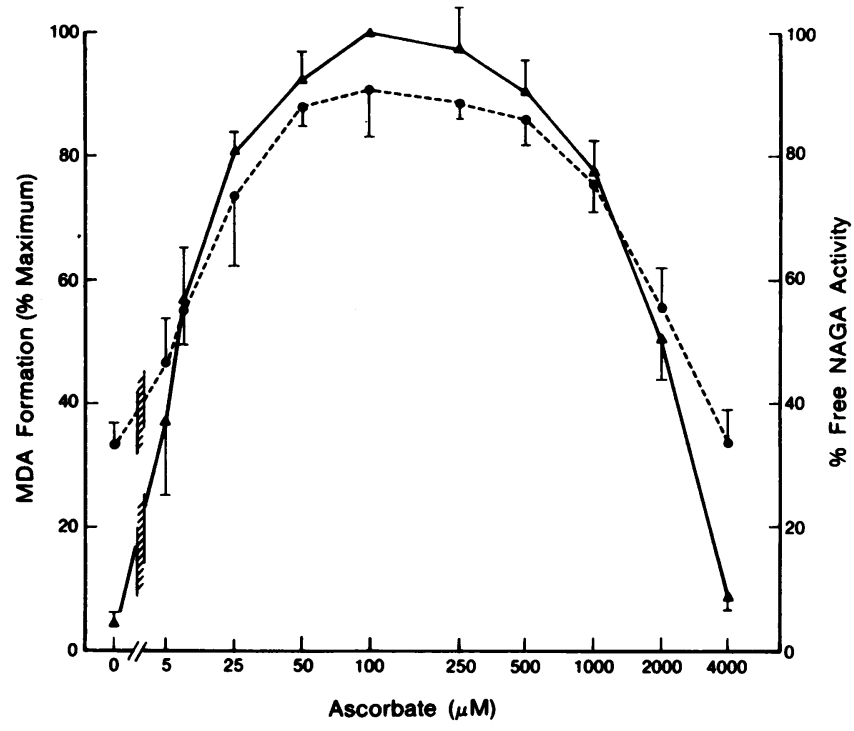

Figure 2. Dose-dependent promotion or inhibition of ascorbate on $\mathrm{Fe}^{3+}$-ADP-mediated lipid peroxidation and loss of latency in lysosomes. Lysosomes were incubated with $0.1 \mathrm{mM} \mathrm{FeCl}_{3}$ chelated by 1 $\mathrm{mM}$ ADP and various levels of ascorbate $(5-4,000 \mu \mathrm{M})$ at $37^{\circ} \mathrm{C}$. After 30 min of incubation, samples were assayed for MDA formation $(\Delta-\Delta)$ and percent-free activity of NAGA ( $\ldots . . .-\bullet) .100 \%$ maximum MDA formation represents $67.0 \pm 6.0 \mathrm{nmol} \mathrm{MDA} / \mathrm{mg}$ protein. Values are mean $\pm S D$ of four separate preparations.

correlated with and may be a direct consequence of various degrees of the induced lipid peroxidation.

Effects of scavengers of active oxygen species on the $\mathrm{Fe}^{3+}$. ADP plus ascorbate mediated lysosomal lipid peroxidation. Ascorbate autoxidizes at neutral pH, especially if metal ions are present $(17,18)$. A few studies suggested that $\mathrm{O}_{2}^{-}(19,20)$ and $\mathrm{H}_{2} \mathrm{O}_{2}(21,22)$ are produced during the autoxidation of ascorbate. Recently, ascorbate was reported $(23,24)$ to be capable of interacting with iron salts to form the hydroxyl radical, which is widely thought to play an important part in initiating lipid peroxidation (25). In an attempt to assess whether active oxygen radicals were involved in the ascorbate dependent $\mathrm{Fe}^{3+}$-ADP-mediated lysosomal lipid peroxidation, various scavengers were added to the lysosomal samples before the additions of ascorbate and $\mathrm{Fe}^{3+}$-ADP. As presented in Table II, scavengers of superoxide radical $\left(\mathrm{O}_{2}^{-}\right)$(superoxide dismutase [SOD]), $\mathrm{H}_{2} \mathrm{O}_{2}$ (catalase) and hydroxyl radical ( $\left.{ }^{\circ} \mathrm{OH}\right)$ (ethanol and mannitol) did not appear to prevent the peroxidation reaction nor protect the loss of latent activity of NAGA. However, both $\alpha$-tocopheral and $t$-retinol, to a lesser extent, effectively prevented the induced lipid peroxidation and substantially protected the loss of the lysosomal latency. Levels of $\alpha$-tocopherol and retinol higher than those indicated in Table II did not provide further inhibition of the peroxidation (data not shown).

Characterization of the role of ferrous iron. Though ascorbate autoxidizes and forms radicals (17), and may also interact with iron salts to generate the hydroxyl radical, our data indicate that neither the ascorbate radical nor any of the active oxygen radicals were responsible for the iron-mediated lipid peroxidation or the disintegration of the lysosomal membrane (Tables I and II). Results in Table III suggest that the primary role of
Table II. Effect of Oxygen Radical Scavengers on Fe ${ }^{3+}-A D P$ + Ascorbate-induced Peroxidative Damage of Hepatic Lysosomes

\begin{tabular}{lcl}
\hline & $\begin{array}{l}\text { MDA formation } \\
\text { (percent of } \\
\text { complete system) }\end{array}$ & $\begin{array}{l}\text { Percent free } \\
\text { NAGA activity }\end{array}$ \\
Additions & & \\
\hline Complete system $\left(\mathrm{Fe}^{3+}-\right.$ & 100 & 90.6 \\
ADP + ascorbate) & 97.3 & 92.1 \\
+ SOD $(10 \mu \mathrm{g} / \mathrm{ml})$ & 94.5 & 88.7 \\
$\quad(50 \mu \mathrm{g} / \mathrm{ml})$ & 96.7 & 89.0 \\
+ Catalase $(10 \mu \mathrm{g} / \mathrm{ml})$ & 90.2 & 87.2 \\
$\quad(50 \mu \mathrm{g} / \mathrm{ml})$ & 91.3 & \\
+ SOD $(50 \mu \mathrm{g})$ & 101.0 & 87.9 \\
+ catalase $(50 \mu \mathrm{g})$ & 102.0 & 85.4 \\
+ Mannitol $(10 \mathrm{mM})$ & 102.5 & 95.2 \\
+ Ethanol $(100 \mathrm{mM})$ & 91.7 & $-{ }^{*}$ \\
+ DABCO $(10 \mathrm{mM})$ & & 93.3 \\
+ Dimethylfuran $(6 \mathrm{mM})$ & 33.9 & 61.3 \\
$+t$-Retinol & & \\
$(0.5 \mu \mathrm{mol} / \mathrm{ml})$ & 6.7 & 49.2 \\
$+\alpha$-Tocopherol & & \\
\hline (1.0 $\mu \mathrm{mol} / \mathrm{ml})$ & &
\end{tabular}

Lysosomes were preincubated with each scavenger for $3 \mathrm{~min}$ at $37^{\circ} \mathrm{C}$ before the additions of ascorbate and $\mathrm{Fe}^{3+}$-ADP. After $30 \mathrm{~min}$ of incubation, samples were assayed for MDA formation and percent-free activity of NAGA. Values are means of two to four separate preparations.

* DABCO at $10 \mathrm{mM}$ is inhibitory to NAGA.

ascorbate was simply to reduce the ferric iron to ferrous iron, which seemed to be the sole "initiator" of peroxidation and subsequent lysosomal membrane disintegration. To determine if the loss of lysosomal latency is due to the induced lipid peroxidation rather than due to the presence of $\mathrm{Fe}^{2+}$ per se, additional control experiments were conducted in the absence of oxygen. Elimination of oxygen from the buffer solution was achieved by purging with nitrogen $\left(\mathrm{N}_{2}\right)$ for at least $30 \mathrm{~min}$.

Table III. Ferrous Iron Alone May Induce

Peroxidative Damage of Lysosomes

\begin{tabular}{lll}
\hline Conditions & MDA formation & $\begin{array}{l}\text { Percent free } \\
\text { NAGA activity }\end{array}$ \\
\hline & $\%$ & \\
$\mathrm{Fe}^{3+}$-ADP + ascorbate & 100.0 & 90.3 \\
$\mathrm{Fe}^{2+}$-ADP & 95.5 & 92.0 \\
$\mathrm{Fe}^{2+}$-ADP + ascorbate & 97.6 & 89.7 \\
$\mathrm{Fe}^{2+}$ & 93.9 & 87.8 \\
$\mathrm{Fe}^{2+}+\mathrm{H}_{2} \mathrm{O}_{2}(100 \mu \mathrm{M})$ & 93.7 & 89.0 \\
$\quad+\mathrm{H}_{2} \mathrm{O}_{2}(300 \mu \mathrm{M})$ & 88.2 & 83.0 \\
$\quad+\mathrm{H}_{2} \mathrm{O}_{2}(1,000 \mu \mathrm{M})$ & 62.5 & $(75.5)^{*}$ \\
\hline
\end{tabular}

Lysosomes were incubated at $37^{\circ} \mathrm{C}$ for $30 \mathrm{~min}$. The indicated additions were: $\mathrm{Fe}^{3+}$-ADP $\left(0.1 \mathrm{mM} \mathrm{FeCl}, 1 \mathrm{mM}\right.$ ADP), $\mathrm{Fe}^{2+}$-ADP $(0.1$ $\left.\mathrm{mM} \mathrm{FeSO}_{4}, 1 \mathrm{mM} \mathrm{ADP}\right)$, Ascorbate $(0.1 \mathrm{mM})$ and $\mathrm{Fe}^{2+}(0.1 \mathrm{mM}$ $\mathrm{FeSO}_{4}$ ). Other conditions were as described in Table I. Values are means of two to four separate preparations.

* $\mathrm{H}_{2} \mathrm{O}_{2}$ at $1 \mathrm{mM}$ or higher partially labilizes the lysosomes. 
The lysosomal suspension in the $\mathrm{N}_{2}$-saturated buffer was further sparged with $\mathrm{N}_{2}$ for 10 min before the addition of 0.1 $\mathrm{mM} \mathrm{Fe}{ }^{2+}$. The samples with or without $\mathrm{Fe}^{2+}$ were then incubated for another $30 \mathrm{~min}$ under continuous $\mathrm{N}_{2}$-sparging for the entire period. Without oxygen, lipid peroxidation in the lysosomes incubated with $\mathrm{Fe}^{2+}$ was greatly inhibited; the level of MDA formed was only $15.5 \pm 3.0 \%(n=4 \pm \mathrm{SD})$ of that exhibited by the paired samples under aerobic incubation. Concomitantly, the free activity of NAGA was substantially reduced to $48.7 \pm 5.6 \%$-free. The modestly elevated free activity of NAGA might be partly caused by the destabilizing effect of gas-sparging, since control samples sparged with $\mathrm{N}_{2}$ (or air) in the absence of $\mathrm{Fe}^{2+}$ also resulted in $45.1 \pm 6.8 \%$ free activity of NAGA. The paired samples incubated with $\mathrm{Fe}^{2+}$ and airsparging exhibited $95.6 \pm 3.5 \%$ free activity of NAGA (with a corresponding MDA of $66.5 \pm 7.0 \mathrm{nmol} / \mathrm{mg}$ protein). These data thus seem to confirm that the loss of lysosomal latency is due to a peroxidative mechanism induced by $\mathrm{Fe}^{2+}$.

Contrary to a recent publication (26), the data in Table III also suggest that ADP was not required as part of the initiation species. A "Fenton system" containing ferrous iron and $\mathrm{H}_{2} \mathrm{O}_{2}$ is an established system for generating $\mathrm{HO}^{\circ}$. The inclusion of various levels of $\mathrm{H}_{2} \mathrm{O}_{2}$ in addition to $\mathrm{Fe}^{2+}$ in our system, however, did not enhance the lysosomal peroxidation and even inhibited at higher concentrations. Presumably $\mathrm{H}_{2} \mathrm{O}_{2}$ and the $\mathrm{OH}$ generated may reduce the effective concentration of $\mathrm{Fe}^{2+}$ through the following reactions: $\mathrm{Fe}^{2+}+\mathrm{H}_{2} \mathrm{O}_{2} \rightarrow \mathrm{Fe}^{3+}$ $+{ }^{\circ} \mathrm{OH}+\mathrm{OH}^{-} ; \mathrm{Fe}^{2+}+{ }^{\circ} \mathrm{OH} \rightarrow \mathrm{Fe}^{3+}+\mathrm{OH}^{-}$(27). These results seem to provide support that ${ }^{\circ} \mathrm{OH}$ was not responsible for the lysosomal peroxidation reaction.

If $\mathrm{Fe}^{2+}$ was the immediate initiating species, the extent of the lysosomal peroxidative degradation should depend on $\mathrm{Fe}^{2+}$ availability when $\mathrm{Fe}^{2+}$ is limiting. Fig. 3 demonstrates that when the lysosomes were incubated for $30 \mathrm{~min}$ with added $\mathrm{Fe}^{2+}$, the levels of MDA production were indeed dependent on the various concentrations until a plateau was reached when the $\mathrm{Fe}^{2+}$ was $>100 \mu \mathrm{M}$. Again, corresponding to the various levels of MDA production were the correlative degrees $(r=0.97$, slope $=0.595)$ of increased percent-free activity of NAGA.

A time course study of the $\mathrm{Fe}^{2+}$ mediated lysosomal lipid peroxidation demonstrated that the MDA formation was promoted readily and reached a maximum within the first 10 min (Fig. 4). In comparison, the initial rate of MDA formation in the $\mathrm{Fe}^{3+}$-ADP + ascorbate system was slower. Inclusions of $100 \mu \mathrm{M}$ ascorbate in the $\mathrm{Fe}^{++}$system did not impede the rapid rate of MDA formation. Therefore, the slower initial rate in the $\mathrm{Fe}^{3+}$-ADP + ascorbate system probably reflected the delayed availability of $\mathrm{Fe}^{2+}$ to initiate the peroxidation reaction. Fig. 4 also indicates that the loss of lysosomal latency was highest within 20 min of incubation, whereas the $\mathrm{Fe}^{3+}$ ADP + ascorbate system required $30 \mathrm{~min}$. The earlier shift of the loss of latency seemed to reflect a greater susceptibility of the membrane lipids to $\mathrm{Fe}^{2+}$.

Additional experiments were conducted to determine if the $\mathrm{Fe}^{2+}$-induced peroxidation was affected by various active oxygen scavengers. Similar to the results presented in Table II, scavengers of $\mathrm{O}_{2}^{-}, \mathrm{H}_{2} \mathrm{O}_{2}$ and $\mathrm{OH}$ were not effective (data not shown). However, $t$-retinol $(0.5 \mu \mathrm{mol} / \mathrm{ml})$ and $\alpha$-tocopherol $(1 \mu \mathrm{mol} / \mathrm{ml}$ ) were able to inhibit the peroxidation 60 and $85 \%$, respectively; whereas the percent-free activities of NAGA were reduced to 65 and $52 \%$, respectively.

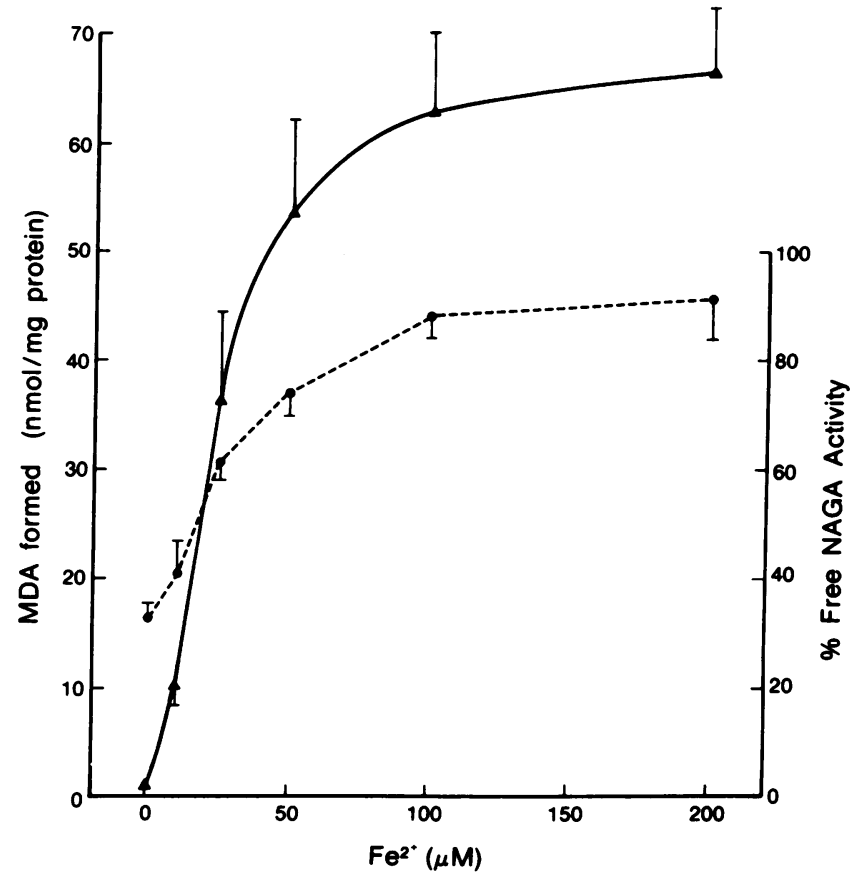

Figure 3. Effect of $\mathrm{Fe}^{2+}$ concentration on lipid peroxidation and loss of lysosomal latency. Lysosomes $(0.20-0.25 \mathrm{mg}$ protein $/ \mathrm{ml})$ were incubated with freshly prepared $\mathrm{FeSO}_{4}(0-0.20 \mathrm{mM})$ at $37^{\circ} \mathrm{C}$ for 30 min. MDA formation ( $\Delta-\Delta)$ and percent-free activity of NAGA $(\bullet----\bullet)$ were determined. Values are mean \pm SD of four separate preparations.

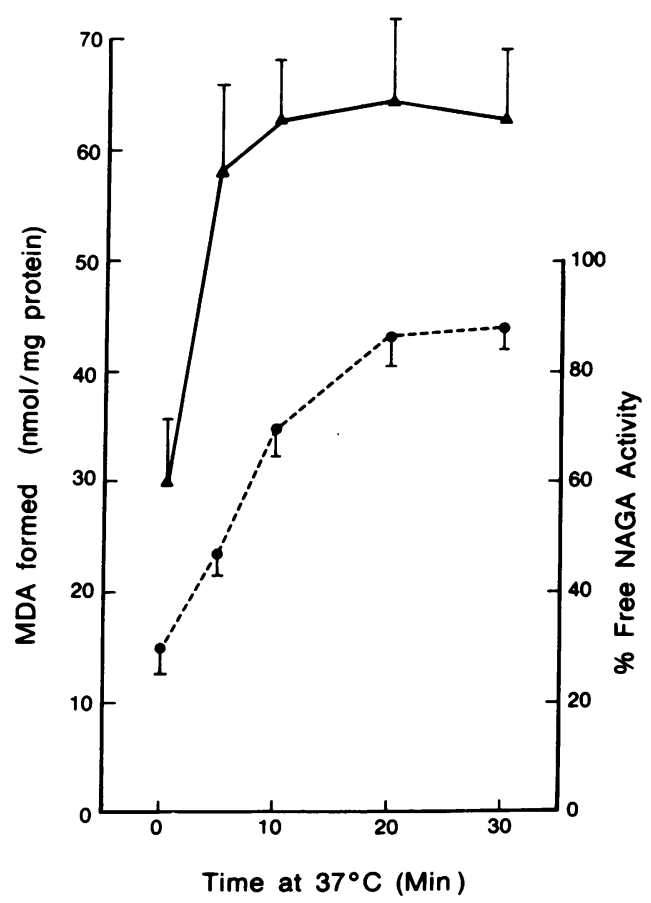

Figure 4. Time course of lipid peroxidation and loss of latency in lysosomes incubated with $\mathrm{Fe}^{2+}$. Lysosomes $(0.20-0.25 \mathrm{mg}$ protein/ ml) were incubated with $0.10 \mathrm{mM} \mathrm{FeSO}_{4}$ at $37^{\circ} \mathrm{C}$. At indicated time of incubation, samples were assayed for MDA formation ( $\Delta-\Delta)$ and percent-free activity of NAGA $(\bullet-. .--\bullet)$. Other conditions were as described in Fig. 1. Values are mean \pm SD of four separate preparations. 


\section{Discussion}

In this report, we have demonstrated that peroxidation of the lysosomes induced by ferric or ferrous iron was not protected by scavengers of $\mathrm{O}_{2}^{-}, \mathrm{H}_{2} \mathrm{O}_{2}$ and ${ }^{\circ} \mathrm{OH}$. Both $\alpha$-tocopherol and retinol are lipid-soluble antioxidants and can quench singlet oxygen, which has been reported to promote lipid peroxidation $(28,29)$. However, other singlet oxygen scavengers, namely DABCO and dimethyfuran, were without effect in our system. The protective effect of $\alpha$-tocopherol and retinol might thus be due to their ability to interact with the membrane phospholipids in the vicinity of the free radical initiated within the membrane to interrupt the chain reaction $(29,30)$. A recent article (30) described that the chain-breaking action of vitamin $A$ may complement that of vitamin $E$, since vitamin $A$ is effective at low oxygen levels and vitamin $E$ is more effective at higher oxygen concentrations. These findings suggest that vitamin A may be a more important protector during tissue ischemic conditions against membrane damage induced by free radicals. Oxygen and $\mathrm{H}_{2} \mathrm{O}_{2}$ can interact by a Haber-Weiss reaction to form ${ }^{\circ} \mathrm{OH}$, which is highly reactive and has been considered to be the ultimate oxygen-derived radical capable of initiating lipid peroxidation $(4,25,27)$. Current dogma suggests that $\mathrm{OH}$ could be generated in our system by the following reactions: $\mathrm{Fe}^{3+}+$ ascorbate $\rightarrow \mathrm{Fe}^{2+}, \mathrm{Fe}^{2+}+\mathrm{O}_{2} \rightarrow$ $\mathrm{Fe}^{2+}-\mathrm{O}_{2} \rightleftarrows \mathrm{Fe}^{3+}+\mathrm{O}_{2}^{-}, \mathrm{O}_{2}^{-}+\mathrm{O}_{2}^{-} \stackrel{\mathrm{H+}}{\rightarrow} \mathrm{H}_{2} \mathrm{O}_{2}, \mathrm{Fe}^{2+}+\mathrm{H}_{2} \mathrm{O}_{2} \rightarrow$ $\mathrm{Fe}^{3+}+\mathrm{OH}^{-}+{ }^{\circ} \mathrm{OH}(27,31)$. Yet our results with different scavengers and the data of the incubation conditions with $\mathrm{H}_{2} \mathrm{O}_{2}$ tend to argue against the involvement of ${ }^{\circ} \mathrm{OH}$ in the initiation of the iron-mediated lysosomal peroxidation, though it may be formed in the reaction mixture. Alternatively, the initiation species might be an iron-oxy compound that has properties similar to the hydroxyl radical (32).

While the molecular interaction of the initiation step remains unknown, our study clearly demonstrates that the susceptibility of the lysosomes to the ferrous form of iron is due to a peroxidative reaction of the membrane lipids, that leads to the liberation of hydrolases. Under normal physiological conditions, intracellular iron (either haem or nonhaem) may be highly compartmentalized (33), however, a trace level of "free iron" or "non-protein-bound iron" is present as well (33-36). It is believed that such a trace level of "non-proteinbound iron" represents a transit pool into which iron enters from transferrin or from endogenous haem breakdown and from which iron is mobilized for synthesis of ferritin and haem (36). In view of the reactivity of the iron, it may be inferred that such a pool must be small and perhaps "compartmentalized" as well. In iron-overload or other pathological conditions, such as drug or chemical toxicities, substantial intracellular decompartmentalization of iron might occur and the tissue content of free iron might increase. In the intracellular milieu, the presence of ubiquitous iron-chelating agents, such as adenine nucleotides and citrate, would probably maintain most of the free iron in the ferric state (36). Ascorbate, present in the hepatic cytosolic fraction, has been estimated to be in the $10^{-4} \mathrm{M}$ range (37), which represents a level compatible with promoting the iron-mediated injury.

Gutteridge et al. (38) recently demonstrated that ascorbate could interact not only with free iron, but also with the iron stored in ferritin fractions, to promote peroxidation of phospholipid liposomes. Apparently, this was due to the ability of ascorbate to release iron from the ferritin form. Clinical evidence suggests that ascorbic acid and iron may affect the metabolism of each other. In patients with transfusional ironoverload, subclinical ascorbate deficiency was common and was thought to be due to accelerated oxidative catabolism of ascorbate as a result of excess iron $(39,40)$. The potential harmful effects of ascorbate were suggested by a recent clinical report that described enhanced toxicity in patients with ironoverload who received oral administration of ascorbate (40).

Subcellular fractionation experiments and cytochemical studies have demonstrated the selective deposition of ferritin, which is subsequently transformed to hemosiderin in the hepatic lysosomes from patients with iron-overload (41). Similar results were reported in iron-overloaded rats. Furthermore, lysosomal integrity in the liver biopsy specimens from the patients with iron-overload, measured by latent or sedimentable activity of NAGA, was strikingly reduced (41); thus, the lysosomes may be a major target of the iron-mediated peroxidative attack and they may participate in the pathogenesis of iron toxicity.

\section{Acknowledgments}

The authors wish to express their appreciation for the helpful discussions of Dr. Robert A. Floyd, the technical assistance of Mark Boomer and the secretarial assistance of Karen Bagby and Kim Hauenstein.

This work was supported by U. S. Public Health Service grants HL-28985, HL-32776, and T-32-07548.

\section{References}

1. Bothwell, T. H., R. W. Charlton, J. D. Cook, and C. A. Finch. 1979. Iron overload-general considerations. In Iron Metabolism in Man. Blackwell Scientific Publications, London, 105-120.

2. Schafer, A. I., R. G. Cheron, R. Dluhy, B. Cooper, R. E. Gleason, J. S. Soeldner, and H. F. Bunn. 1981. Clinical consequences of acquired transfusional iron overload in adults. N. Engl. J. Med. 304:319-324.

3. Wills, E. D. 1969. Lipid peroxide formation in microsomes. The role of non-haem iron. Biochem. J. 113:325-332.

4. McCay, P. B., and J. L. Poyer. 1976. Enzyme-generated free radicals as initiators of lipid peroxidation in biological membranes. In The Enzymes of Biological Membranes. A. Martonosi, editor. Plenum Publishing Corp., New York. 4:239-256.

5. Svingen, B. A., and S. D. Aust. 1980. The mechanism of NADPH-dependent and $\mathrm{O}_{2}$-dependent lipid peroxidation. In Molecular Basis of Environmental Toxicity. R. S. Bhatnagar, editor. Ann Arbor Science Publishing, Inc., Ann Arbor, MI. 69-110.

6. Jacobs, A. 1980. The pathology of iron overload. In Iron in Biochemistry and Medicine. A. Jacobs and M. Worwood, editors. Academic Press, London. II:427-459.

7. Dougherty, J. J., W. A. Croft, and W. G. Hoekstra. 1981. Effect of Ferrous Chloride and iron-dextran on lipid peroxidation in vivo in Vitamin E and salenium adequate and deficient rats. J. Nutr. 111:17841796.

8. Goddard, J. G., and G. D. Sweeney. 1983. Ferric nitrilotriacetate: A potent stimulant of in vivo lipid peroxidation in mice. Biochem. Pharmacol. 32:3879-3882.

9. Bacon, B. R., A. S. Tavill, G. M. Brittenham, C. H. Park, and R. O. Recknagel. 1983. Hepatic lipid peroxidation in vivo in rats with chronic iron overload. J. Clin. Invest. 71:429-439.

10. Mak, I. T., H. P. Misra, and W. B. Weglicki. 1983. Temporal relationship of free radical-induced lipid peroxidation and loss of latent enzyme activity in highly enriched hepatic lysosomes. J. Biol. Chem. 258:13733-13737.

11. Henning, R., and H.-G. Heidrich. 1974. Membrane lipids of 
rat liver lysosomes prepared by free-flow electrophoresis. Biochim. Biophys. Acta. 345:326-335.

12. Ruth, R. C., and W. B. Weglicki. 1978. The temperaturedependent of the loss of latency of lysosomal enzymes. Biochem. J. 172:163-173.

13. Lowry, A. H., N. J. Rosenbrough, A. L. Farr, and R. J. Randall. 1951. Protein measurements with the Folin phenol reagent. J. Biol. Chem. 193:265-275.

14. Wills, E. D. 1969. Lipid peroxidation in microsomes. General considerations. Biochem. J. 113:315-324.

15. Will, E. D. 1972. Effects of iron overload on lipid peroxide formation and oxidative demethylation by the liver endoplasmic reticulum. Biochem. Pharmacol. 21:239-247.

16. Kanner, J., and H. Mendel. 1977. Pro-oxidant and anti-oxidant effects of ascorbic acid and metal salts in a $\beta$-carotene-linoleate model system. J. Food Sci. 42:60-64.

17. Bielski, B. H. J., H. W. Richer, and P. C. Chan. 1975. Some properties of the ascorbate free radical. Ann. N.Y. Acad. Sci. 258:231237.

18. Halliwell, B., and C. H. Foyer. 1976. Ascorbic acid, metal ions and the superoxide radical. Biochem. J. 155:697-700.

19. Puget, K., and A. M. Michelson. 1974. Iron containing superoxide dismutase from luminous bacteria. Biochimie. 56:12551267.

20. Hirata, F., and O. Hayaishi. 1975. Studies on indoleamine 2,3dioxygenase I. superoxide anion as substrate. J. Biol. Chem. 250:59605966.

21. Peterkofsky, B., and W. Prather. 1977. Cytotoxicity of ascorbate and other reducing agents towards cultured fibroblasts as a result of hydrogen peroxide production. J. Cell. Physiol. 90:61-70.

22. Koch, C. J., and J. E. Biaglow. 1978. Toxicity, radiation sensitivity modification, and metabolic effects of dehydroascorbic and ascorbate in Mammalian cells. J. Cell. Physiol. 94:299-306.

23. Winterbourn, C. C. 1981. Hydroxyl radical production in body fluids. Roles of metal ions, ascorbate and superoxide. Biochem. J. 198:125-131.

24. Rowley, D. A., and B. Halliwell. 1983. Formation of hydroxyl radicals from hydrogen peroxide and iron salts by superoxide- and ascorbate-dependent mechanism: relevance to the pathology of rheumatoid disease. Clin. Sci. 64:649-653.

25. Freeman, B. A., and J. D. Crapo. 1982. Biology of disease. Free radicals and tissue injury. Lab. Invest. 47:412-426.

26. Svingen, B. A., J. A. Buege, F. O. O'Neal, and S. D. Aust. 1979. The mechanism of NADPH-dependent lipid peroxidation. $J$. Biol Chem. 254:5892-5899.

27. Willson, R. L. 1979. Hydroxyl radicals and biological damage in vitro: what relevant in vivo? In Oxygen Free Radicals and Tissue Damage. Ciba Foundation Symposium 65. Excerpta Medica, Amsterdam. $19-42$.

28. Kellogg, E. W., III, and I. Fridovich. 1975. Superoxide, hydrogen peroxide and singlet oxygen in lipid peroxidation by a xanthine oxidase system. J. Biol. Chem. 250:8812-8817.

29. McCay, P. B., K.-L. Fong, E. Lai, and M. M. King. 1978. Possible role of vitamin $\mathrm{E}$ as a free radical scavenger and singlet oxygen quencher in biological systems which initiate radical-mediated reactions. In Tocopherol, Oxygen and Biomembranes. C. deDuve and O. Hayashi, editors. Elsevier/North-Holland Biomedical Press, Amsterdam. 41-57.

30. Burton, G. W., and K. U. Ingold. 1984. $\beta$-Carotene: An unusual type of lipid antioxidant. Science (Wash. DC). 224:569-573.

31. Gutteridge, J. M. C. 1982. The role of superoxide and hydroxyl radicals in phospholipid peroxidation catalysed by iron salts. FEBS (Fed. Eur. Biochem. Soc.) Lett. 150:454-458.

32. Fee, J. A. 1980. Superoxide, superoxide dismutases, and oxygen toxicity. In Metal Ion-Activation of Dioxygen. T. G. Spiro, editor. John Wiley \& Sons, Inc., New York.

33. Willson, R. L. 1977. Iron, zinc, free radicals and oxygen in tissue disorders and cancer control. In Iron Metabolism; Ciba Foundation Symposium 51. Elsevier/Excerpta Medica/North-Holland, Amsterdam. 331-354.

34. Halliwell, B., and J. M. C. Gutteridge. 1984. Oxygen toxicity, oxygen radicals, transition metals and disease. Biochem. J. 219:1-14.

35. Fong, K.-L., P. B. McCay, J. L. Poyer, H. P. Misra, and B. B. Keele. 1976. Evidence for superoxide-dependent reduction of $\mathrm{Fe}^{3+}$ and its role in enzyme-generated hydroxyl radical formation. Chem. Biol. Interact. 15:77-88.

36. Jacobs, A. 1977. An intracellular transit iron pool. In Iron Metabolism. Ciba Foundation Symposium 51. Elsevier/ Excerpta Medica/North-Holland, Amsterdam. 91-106.

37. Wright, J. R., H. D. Colby, and P. R. Miles. 1981. Cytosolic factors which affect microsomal lipid peroxidation in lung and liver. Arch. Biochem. Biophys. 206:296-304.

38. Gutteridge, J. M. C., B. Halliwell, A. Treffry, P. M. Harrison, and D. Blake. 1983. Effect of ferritin-containing fractions with different iron loading on lipid peroxidation. Biochem. J. 209:557-560.

39. Charlton, R. W., and T. H. Bothwell. 1976. Iron, ascorbic acid, and thalassemia. Birth Defects. 12:63-79.

40. Nienhuis, A. W. 1981. Vitamin C and iron. N. Engl. J. Med. 304:170-171.

41. Peters, T. J., and C. A. Seymour. 1976. Acid hydrolase activities and lysosomal integrity in liver biopsies from patients with iron overload. Clin. Sci. Mol. Med. 50:75-78. 